University of Nebraska - Lincoln

DigitalCommons@University of Nebraska - Lincoln

Faculty Publications from the Harold W. Manter Laboratory of Parasitology

3-1948

\title{
Dendrouterina botauri n. sp., a Cestode Parasitic in Bitterns, with Remarks on Other Members of the Genus
}

Robert L. Rausch

University of Wisconsin - Madison, rausch@u.washington.edu

Follow this and additional works at: https://digitalcommons.unl.edu/parasitologyfacpubs

Part of the Parasitology Commons

Rausch, Robert L., "Dendrouterina botauri n. sp., a Cestode Parasitic in Bitterns, with Remarks on Other Members of the Genus" (1948). Faculty Publications from the Harold W. Manter Laboratory of Parasitology. 574.

https://digitalcommons.unl.edu/parasitologyfacpubs/574

This Article is brought to you for free and open access by the Parasitology, Harold W. Manter Laboratory of at DigitalCommons@University of Nebraska - Lincoln. It has been accepted for inclusion in Faculty Publications from the Harold W. Manter Laboratory of Parasitology by an authorized administrator of DigitalCommons@University of Nebraska - Lincoln. 


\title{
Dendrouterina botauri n. sp., A Cestode Parasitic in Bitterns, With Remarks on Other Members of the Genus*
}

\author{
Robert Rausch \\ Department of Veterinary Science, University of Wisconsin, Madison
}

A single cestode belonging to the genus Dendrouterina Fuhrmann, 1912, was taken from the small intestine of a least bittern, Ixobrychus e. exilis (Gmelin), collected by the writer on May 31, 1945, at Buckeye Lake, Ohio. Considerable difficulty was experienced in obtaining adequate material of this cestode, although bitterns were collected in Ohio, Michigan, Wisconsin, and Manitoba. A second infected bird, an American bittern, Botaurus l. lentiginosus (Monatgu), was collected on April 24, 1947, at Horicon Marsh, Wisconsin. Three specimens of Dendrouterina were obtained from this bird.

Unfortunately, since refrigeration was not available in the field, the scolices of all four specimens had degenerated by the time the autopsies were made. However, since this species is so obviously different from those previously described, the description is presented with this inadequacy.

Whole-mounts, stained with Semichon's acetic carmine, were made, and all observations were substantiated by observations on frontal and transverse serial sections, cut at $15 \mu$, and stained with haematoxylin-eosin.

\section{Dendrouterina botauri n. sp.}

Diagnosis.-Strobila about $150 \mathrm{~mm}$ long; maximum width, attained in gravid proglottids, about $2 \mathrm{~mm}$. Strobila consists of about 140 proglottids. Margins of mature proglottids serrate, while margins of gravid proglottids are ccnvex. Longitudinal muscle fibers numerous, arranged several deep in apparently a single layer. Transverse muscle fibers not seen. Scolex unknown.

Ventral excretory canals about 30 to $50 \mu$ in diameter; their course somewhat undulating. Aporal ventral excretory canal situated dorsally, while poral canal is in usual ventral position. Transverse canals about $20 \mu$ in diameter in central area of segment, and narrower near junction with longitudinal canals. Transverse canals situated just behind testes near posterior border of the proglottid; accessory canals, which transverse the proglottids in an irregular manner, may be present. The dorsal canals are about $2 \mu$ in diameter in mature proglottids.

Genital ducts dorsal to longitudinal excretory vessels. Genital pores unilateral and dextral, situated near the anterior margin of the proglottid. Genital atrium deep; not lined with chitinous spines.

* This work supported in part by the Research Committee of the Graduate School from funds supplied by the Wisconsin Alumni Research Foundation. 
Rausch in American Midland Naturalist (March 1948) v. 39, no. 2.

Copyright 1948, University of Notre Dame. Used by permission.
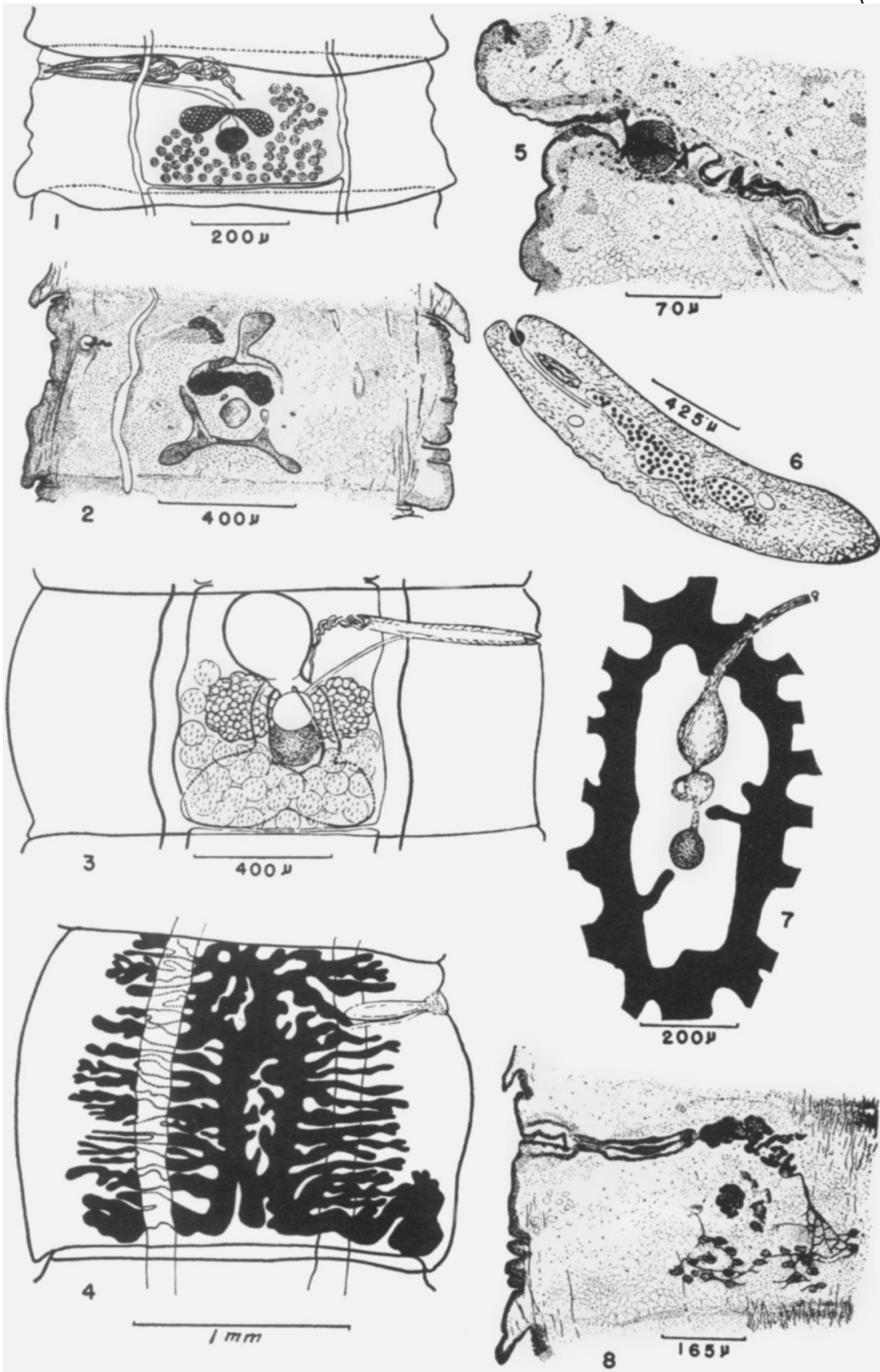

Figs. 1-8. Dendrouterina botauri n. sp.-1. Typ!cal mature proglottid, from Botaurus (ventral view). 2. Frontal section of an early post-mature proglottid from Botaurus (ventral view). 3. Later post-mature proglottid, from Ixobrychus (dorsal view). 4. Gravid proglottid, from Ixobrychus (dorsal view). 5. Frontal section showing details of terminal part of vagina, from Botaurus. 6. Cross section showing position of ventral excretory canals from Ixobrychus. 7. Central area of gravid proglottid showing seminal receptacle and vitelline gland, from Ixobrychus. 8. Frontal section showing details of male reproductive organs, from Botaurus. 
Cirrus sac dorsal and somewhat anterior to vagina; it measures from 254 to $380 \mu$ in mature proglottids. Cirrus sac thick-walled, and may extend beyond ventral excretory canal nearly to mid-line in mature proglottids. Cirrus spined, and somewhat coiled within cirrus sac. There appears to be a very small internal seminal vesicle, but this was not always visible in sectioned material. External seminal vesicle absent. Vas deferens forms numerous coils medial to end of cirrus sac. Testes are ovoid, from 45 to 56 in number (average 49), and are situated posterior, lateral, and mostly dorsal to female reproductive organs. Testes measure from 23 to $36 \mu$ long by 20 to $26 \mu$ wide (average 31 by $22 \mu$ ) in mature proglottids. Testes enlarge in post-mature proglottids, before disappearing. On aporal side of proglottid, testes extend forward to level of genital pore; on poral side to level of anterior margin of the ovary. Testes lie mainly in same plane, not more than two deep, and concentrated more in the lateral fields. They do not extend laterally beyond the longitudinal excretory canals. Testes are connected by a network of vasa efferentia, which usually arise from the antero-dorsal surface of the o:gans.

Vagina is ventral and slightly posterior to cirrus sac; it is provided with a large sphincter, about $50 \mu$ in diameter, at the genital atrium. Vagina runs medially toward the ovary, with few undulations, to join large seminal receptacle between ovary and vitelline gland, and ventral to the latter. The ovary consists of two ovoid lobes connected by a narrow band; the lobes become spherical and enlarged in the post-mature proglottids. Vitelline gland is large and spherical; situated immediately posterior to ovary on the mid-line.

Uterus is first visible as an ovoid to spherical sac antericr to the ovary, and gradually extending to anterior margin of the proglottid. The early uterus completely surrounds the ovary and vitelline gland, ventral to them. Three enlargements are seen in the early uterus; one anterior to the ovary, and two posterior. The post-mature proglottids, along with the uterus, elongate rapidly, and lateral branches appear on the latter. The hollow center of the uterus is retained, and, as the proglottids become older, the side branches elongate and subdivide. The poral edge of the gravid uterus is dorsal to the ventral excretcry canal, while the aporal edge is ventral to the aporal ventral canal. The vitelline gland and seminal receptacle, along with the vagina and cirrus-sac, are retained in the fully gravid proglottids. Shape of gravid uterus is somewhat variable. Eggs are not densely packed.

The embryos measure $25 \mu$ in diameter, with hooks about $8.4 \mu$ in length. Outside diameter of egg about $33 \mu$. Shell unusually delicate and often not visible.

Host.-Botaurus l. lentiginosus (Montagu) (American bittern), and Ixobrychus e. exilis (Gmelin) (least bittern).

Habitat.-Small intestine.

Locality.-Buckeye Lake, Ohio (Ixobrychus), and Horicon Marsh, Wisconsin (Botaurus).

Type.-A total preparation from Botaurus has been deposited in the Helminthological Collection of the U. S. National Museum. 


\section{Discussion}

The genus Dendrouterina was erected by Fuhrirann (1912) for a cestode, $D$. herodiae Fuhrmann, 1912, from an egret, Garzetta garzetta (Lin.) as typs. Dendrouterina botauri differs from $D$. herodiae in the formation and shape of the gravid uterus. In $D$. herodiae the gravid uterus is "hifeisenförmig," and not closed posteriorly. In $D$. botauri the uterus is completely closed posteriorly; it surrounds the female reproductive organs in the early mature proglottid (fig. 2), and encloses the seminal receptacle and vitelline gland in fully gravid proglottids (figs. 4 and 7 ).

Especially characteristic of $D$. botauri is the formation of the utzrus, wh:ch, when first observed in post-mature proglottids, entirely surrounds the ovary and vitelline gland, with a single anterior enlargement, and two posterior ones (figs. 2 and 3). As seen in Fuhrmann's (1912) figure 5, the uterus in $D$. berodiae is net-like in its early stages of formation, while this is not true of that of $D$. botauri.

Dendrouterina botauri is larger than $D$. herodiae, and apparently has a greater number of testes. If each species is found to possess an armed rostellum, it is possible that theie will be differences in the number and size of the hooks. According to Dr. J. G. Baer (personal communication) the genital atrium of $D$. herodiae "is very peculiar in that it is muscular and lined with long, thin, chitinous spines." The genital atrium of $D$. botauri is not lined with such spines, as disclosed by the examination of serial sections under oil immersion.

Three other species have been assigned to the genus Dendrouterind, but, for reasons pointed out below, their inclusion in this genus is not acceptable.

The diagnosis of the genus Dendrouterina was given by Fuhrmann (1912) as follows: "Skolex unbekannt. Die Geschlechtsgänge gehen zwischen den Wassergefässen durch zur Genitalkloake, die Genitalöffnungen sind einseitig; dic zahlreichen Hoden hinter den weiblichen Geschlechtsdrüsen; Uterus hufeisenförmig mit besonders zahlreichen seitlichen Verzweigungen, welche auf der poralen Seite über, auf der antiporalen Seite unter dem weiten Längsgefäss durch ins Rindenparenchym dringen. Das Wassergefässsistem zeigt auf der antiporalen Seite das enge, sonst dorsale Längsgefäss ventral von weiten Exkretionsstamm."

It is evident from this that a highly-branched uterus and a dorsally-placed aporal ventral excretory canal are requisite characters of the genus.

According to Dr. J. G. Baer (personal communication), who has just examined Fuhrmann's original material, the genital ducts are dorsal to the longitudinal excretory canals in $D$. herodiae, and do not pass between them, as was originally stated.

Dendrouterina fovea Meggitt, 1933, was the second species to be assigned to the genus. Unfortunately, Meggitt's description is inadequate, so that many 
details are not available. It was stated, however, that the uterus is "a branched sac, not extending laterally to the excretory vessels." The gravid uterus was not figured, and no mention was made of the typical arrangement of the ventral excretory canals; a feature which, if present, could hardly have been overlooked. Dendrouterina fovea was also parasitic in a passeriform bird, while both $D$. herodiae and $D$. botauri are parasites of ardeiforms.

Dendrouterina nycticoracis Olsen, 1937, and D. lintoni Olsen, 1937, were described from ardeiform birds. Through the kindness of Dr. E. W. Price, the writer had the opportunity of examining Olsen's original material. The gieat size difference is at once apparent; both $D$. nycticoracis and D. lintoni being relatively very small. The genital ducts in Olsen's species pass between the excretory canals, instead of dorsal to them, as is the case in the genus Dendrouterina. Serial sections of $D$. nycticoracis and $D$. lintoni were unfortunately not available to the writer, but there is no indication that the ventral excretory canals have the arrangement typical for the genus. According to Olsen (1937b), "in Dendrouterina the ventral duct on the poral side is large and the dorsal one minute, whereas the opposite condition obtains on the aporal side." Examination of whole mounts and serial sections of $D$. botauri reveals that Fuhrmann's original conclusion is correct in regard to the arrangement of these canals; he stated that "Das Wassergefässsystem z.eigt deutlich ein Paar sehr weiter Längsgefässe, welche ein ebenfalls weites, an Hinterrand der Glieder liegendes Quergefäss aufweisen." There can be no error in assuming this arrangement, since, in frontal serial sections of $D$. botauri, the large ventral canals were obviously connected by transverse canals, and the dorsal canals showed only the usual arrangement.

The gravid uteri of $D$. lintoni and $D$. nycticoracis do not resemble in the least that of $D$. botauri, nor, as far as can be determined from Fuhrmann's figure, that of $D$. herodiae. The gravid uteri of the former two species are typical, sac-like, somewhat lobed dilepidid uteri, without the central opening, and without the characteristic branchings. The gravid uterus in $D$. botauri is more comparable in appearance with that found in the genera Ta:nia and Cladotaenia. In the opinion of the writer, D. lintoni and D. nycticoracis belong in the genus Dilepis Weinland, 1858.

With only $D$. herodiae and $D$. botauri remaining in the ginus, the type of scolex remains unknown. It is hoped that this will prove to be of some value in determining the relationships of Dendrouterina. Fuhrmann (1912) stated "Über die Stellung dieses Genus im System ist es schwer sich auszusp"echen, da der Skolex leider unbekannt ist. Nach der Muskulatur zu urteilen, gehört das Genus vielleicht den Anoplocephaliden an, ich stelle aber c'asselbe votläufig in die Familie der Dilepiniden." The genus has been retained in the family Dilepididae, but it will probably be placed elsewhere after additionai material has been studied.

\section{SUMMARY}

1. A new species of cestode, Dendrouterina boutauri, is described from North American bitterns. 
2. Three other species previously assigned to the genus Dendrouterina are discussed, and it is concluded that they belong elsewhere. The description of $D$. fovea Meggitt, 1933, is not adequate to allow its assignment to the proper genus, but D. lintoni Olsen, 1937, and D. nycticoracis Olsen, 1937, are considered as belonging in the genus Dilepis Weinland, 1858.

3. Two species are now known for the genus Dendrouterina; they are $D$. herodiae Fuhrmann, 1912, and $D$. botauri $\mathrm{n}$. sp. The scolices are unknown for both.

\section{Acknowledgment}

The writer is indebted to Dr. J. G. Baer, Direcior of the Insititut de Zoologie, Université de Neuchâtel, for details resulting from his examination of Fuhrmann's criginal material, and for very !helpful suggestions; to Dr. E. W. Price, Zoological Division, Bureau of Animal Industry, for the loan of Olsen's type material; and to Mr. Wayne Truax, Leader, Pittman-Robertson Muskrat Project, Horicon Marsh, $\mathrm{W}$ isconsin, for aid in obtaining bitterns from that area.

\section{REFERENCES}

FuhrmanN, O. 1912-Ergebnisse der mit Subvention aus der Erbschaft Tre:tl unternommenen zoologischen Forschungsreise Dr. Franz Werner's nach dem ägyptischen Sudan und Nord-Uganda. XXI. Vogelcestoden. Sitzungsb. K. Akad. Wiss. Wien, Math.-Naturw. Klasse 121:181-192.

MegGitt, F. J. 1933-Cestodes obtained from animals dying in the Calcutia Zoological Gardens during 1931. Rec. Ind. Mus. 35-145-165.

Olsen, O. W. 1937a-A new species of cestode, Dendrouterina nycticoracis, from the black-crowned night heron (Nycticorax nycticorax hoactli) (Gmelin). Proc. Hel. Soc. Wash. 4:30-32.

1937b-A new species of cestode, Dendrouterina lintoni (Dilepididae), from the little green heron, (Butorides virescens) (Linn.) Ibid. 4:72-75. 